quently some of it escapes, or the demand on our vital not been interrupted, ague is unknown. Like a really sci. they were weighed night and morning and unleas the was

quently some of it escapes, or the demand on our vital
energy made to assimilate the vegetable food takes too much away from our otber working powers.

Notbing is wanted bere but more science applied to cookery; the problem is clearly definable and defined, and is ob-
viously less difficult than others that science bas already solved. tritive constituents of vegetables, such as pecten, the jelly fruits ; and the saline juices of vegetables that contain all similar value as completing the dietary. They are sijoject
to little or $n$ o change in cookery, are quite as good when raw as after being cooked.

In connection with this, I must again be egotistica!, by proclaiming another result of my own resea ches, viz., the and boiled or steamed potatoes, and between potaloes boiled in their jackets, and potatoes peeled before boiling. I find potash in the water in which potatoes bave been boiled It of the potato pass out by exosmosis into the water. By
baking them, or frying them, this is entirely prevented baking them, or frying them, this is entirely prevented.
We all know that there is a difference between a baked and We all know that there is a difference between a baked and
a boiled potato. I attribute it mainly to this. a boiled potato. I attribute it mainly to this.
As regards the grear question of jackets or no jackets, 1 As regards the greal question of jackets or no jackets,
can only speak theoretically at present. I suppose that the natural envelope does resist the out-going of some of these saline juices, but bave not yet proved it analytically. The bighest of all practical authorities on this subject, the Irish
peasant, bas very firmly decided for himself. I bave never seen raw potatoes in a state of nakedness in Ireland, and
suspect that nalural appetite bas discovered that there is suspect that natural appetite bas discovered that there is
something in the full-dressed potato that is demanded in the something in the full-dressed potato that is demanded in the
system, just as it teaches the sailor to crave for potaslı food, as 1 and my fellow cheese eater did in Greece. vegetables of similar composition, unless the water in which vegetables of similar composition, unless the water in which be due to the better retention of the potash by the undercooked tuber. cooked tuber.
I must now conclude with apologg for the necessary im- $-\begin{aligned} & \text { a copse carpet of primroses, antemones, or byacinths, } \\ & \text { stretch of gray and purple bearber, a bank of gorse or } \\ & \text { perfections of this very short sketch of a large subject, } \\ & \text { broom, an old alder bed full of glowing mars marigold }\end{aligned}$ $\begin{array}{lll}\text { tres. } & \text { broom, an old alder hed full of glowing marsh marigold } \\ \text { bave } & \text { and then are the useful natural lessons to be learnt by bear } \\ \text { and copied or exactly transcribed into our garden }\end{array}$

\section{COLOR IN THE FLOWER GARDEN.}

THE sizes of groups must be in proportion to space; $\mathrm{m}$ o accommodate goodsized clumps of the best bardy flowers. The principle of harmonious coloring will produce the large of the same plant, because the "effect" is spread over the whole of one mass of barmoniously colored flowers, if the
mass is well composed and combined. This is the very reverse of bedding, with its rigid blocks and patterns of color
How to arrange the groups of plants may be best learnt by, careful study of nature. Purely natural forms of flowe ouping must not be looked for in fields and hedges, because but rather in old woods, riversides, and moorland. Ther may be seen the "large effects"-a straggling mass of - forcopse carpet of primroses, anemones, or byacintbs,
itretch of gray and purple bearber, a bank of gorse a rain in the night, they uniformly weighed less in the morn ing than at night, the loss being from one to three ounces
for the loam and one to four ounces forthe peat. This Prof. Stockbridge thought indicated that the soil at night gave forth water, and that the moisture found on the surface of field in the morning came from a deeper soil rather than a cabbage plant was inclosed in an air-tight tin case. Where the stem of the plant protruded tbrough the top of the case,
wax was used to make it impossible for moisture to escape through the leaves. The can was first kept within doors and iug the night of from $1 \cdot 21$ grammes to $1 \cdot 78$ grammes. When eft out of doors at night, with the can wrapped in cloth to prevent moisture reaching it, the loss was from 0.55
grammes to 4.23 grammes, showing a loss ever'when there was moisture or dew on the leaves.
These experiments, continued through the season, gave Prof. Stockbridge these proofs of his proposition, that the dew on the ground in the summer is the condensation of
vapor that rises from the eartb. 1. The vapor of the soil is much warmer at night than the air, and would be condense by it. 2. Vapor from the soil is soon diffused and equalized in the whole atmosphere, but in largest proportion when most dew 3. Dew under baycocks, boards, and like objects on the ground could receive it from no other source.-Indusrialist

THE LAST OF THE JEANNETTE EXPLORING EXPEDITION.

With the home-coming of the bodies of De Long and bis expedition in the Jeannette comes to an end. While serving as navigator of the Juniata, sent by the Navo Department to the Greenland coast in search of Capt. Fall's expedition in the Polaris, Lieutenant De Long ob of Arctic affairs led him to the belief that the route by Behring's Straits was the most promising way to the pole. He mersuaded Mr. Bennett of the Herald that personal fame and
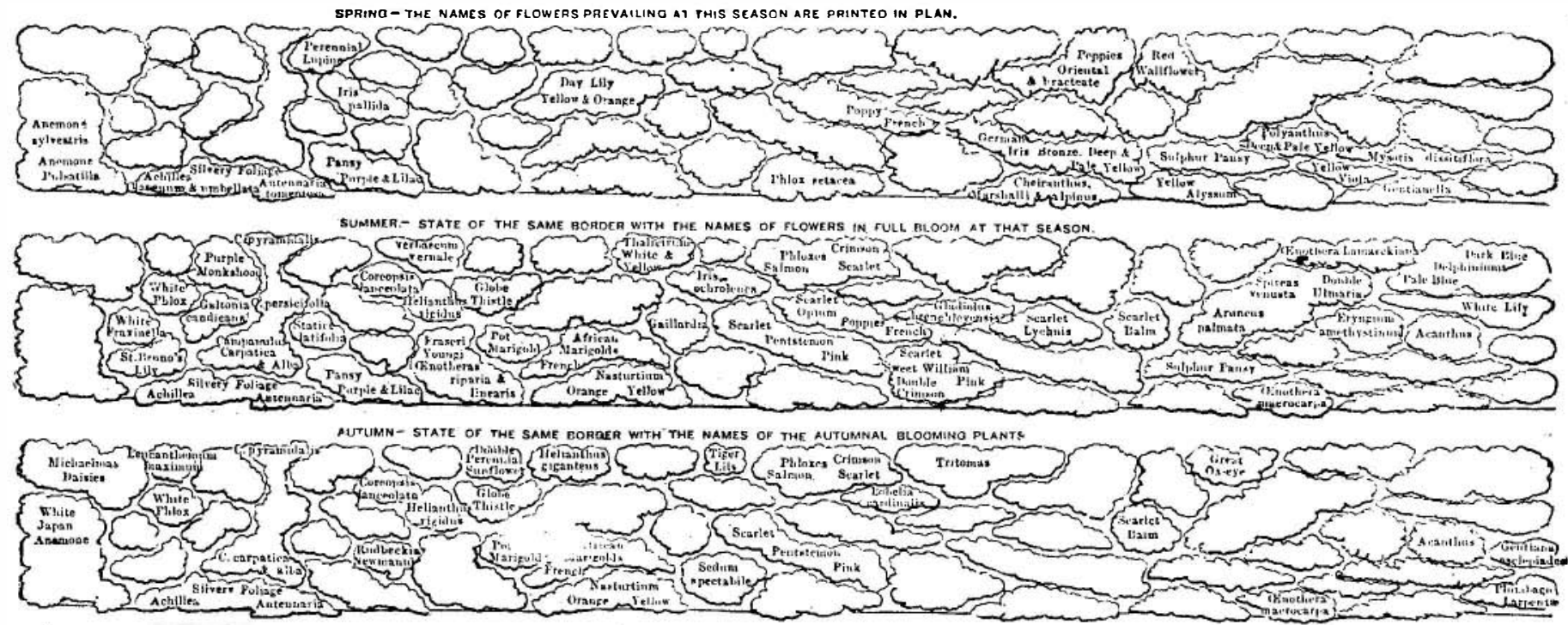

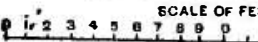

ISection of $a \bar{a}$ ardy plant border, showing the arrangement of the principal plants. Bulbs and numerou
the plan, though internnixed with the larger masses.

been well spent, if they bave only awakrned ari interest in
the subject, and induced you to prosecute it further, by the subject, and induced you to prosecute it further, by
proving that there really is a "scientific basis of cookery."

THE EFFECTS OF A WARM FOOT BATH. Is order to determine whether warm foot baths were any value as a derivative in cerebral congestion, or as a
means of inducing a congestion of the pelvic organs, Dr. Sciolcowsky made a number of observations, noting the changes of temperature in the external auditory meatus, was from fifteen to i went.y minutes, and the temperature of the water was from $92^{\circ}$ to $97^{\circ}$. He found that the temperitture rose in the axilla and external auditory meatus, while
fell in the rectum. The volume of the vessels in the uppe extremities was decreased. There was an increase in the observations showed that the warm foot bath diminishes
the flow of bloot to the abdominal and pelvic organs, while at the same time there is an increased flow to the superficial parts. The foot hath, then, neither diminishes the by peræmia of the brain and its envelopes nor increas
that of the pelvic organs.-Memorabilien, N 1 . 7, 1883 .

OBSE RVATIONS ON MALARIA.

Dr. HARveY, of Orange, N. Y., contributes to the Sanibe has studied as they appear around bim, recording bis observations with an intelligence and freedom from prejudice which make them doubly valuable. Considerable postions
of the towns of Orange, Bloomfield, and Belleville lie nea the banks of a small stream, which is interrupted at intervals
by mill dams. Of the families living in the valley of this by mill dams. Of the families living in !be valley of this
stream, ninety per ccnt., accordiny to Dr. Harvey's estimate stream, ninely per ccnt., accordiny to Dr. Harvey's estimate, within the last five years. As a partial compensation for this tive fevers are less cummon in the malarial district than in the bealthier regions, but the constant prevalence of a dis-
ease which at tacks nearly all the inbabitants at short intervals, and keeps even those who escape acute symptoms under a depressing influence, is a serious calamity. Local
opinion attributes the miasma of the valley to the mill ponds, and although the mill owners strenuously deny that thei itber places near by, where the water courses, althoug ying in a similar relation to the region about them, bave but interpreted in sucb a way as may best suit our space and and I can confidently recommend it to orbers. Let " $\mathrm{S}$.",
accept my assurance and claim the welcome offered to good gardeners, next June or any time between April and with "large effects" and "painted like a picture" is nol only possible, but eminently practicable.-G. J., The Garden.

A NEW THEORY OF DEW

By Prof. B. F. Nihart, A.M.

Invastigations which Prof. Stockbridge bas made at the peratures of the soil and air. and the deposition of dew upothe earth and plants, bave led bim to conclusions very dif tion of dew. It is usually beld that dew is the moisture of
then the the air, condensed through contact with objects of a lower
temperature, and that it does not form until radiation bas reduced the temperature of the earth and other objects below that of the atmosphere. The experiments referred to seem to indicate that as regards objects in the immediate vicinity of
the earth at least, the process is the converse of this, viz. that the dew is the result ot condensation by the air of warm vapor as it rises from the soil. The course of experiments ollow:

The basis of the theory is the discovery that in summer the arage temperalure of the earth at night is greater tha that of the atmosphere. The temperature of the earth in an temperature of the air, were taken at the warmest time of average temperature of the air for the season was found $72.94^{\circ}$, and that of the soil $72 \cdot 061^{\circ}$; but the average temperture of the air at night was $49 \cdot 664^{\circ}$, and that of the soil
$56.37^{\circ}$, the earth thus averaging at night over $6^{\circ}$ warmer than the atmosphere. The temperature of the soil and air night was also taken at various points within ten miles of the college, on all kinds of grass land and bare soil, and in
the same facts were obtained, the soil being at all times warmer at night than the ait.

The results led to experiments on dew-fall. Two boxes disarranging its strata, one receiving absorbent, retentive loam, and the other peat. These boxes were placed in a trench in an open field level with the surrounding ground
and exposed to the weather. Through the month of to meet all the costs of the venture. A vessel named the 80 borse-power engine, was purchased for the Herald expeBritish and renamed the Jeannette. Built originally for a British naval dispatch boat, in 1864, she bad been specially
strengthened for Arctic service by ber late owner. Sir Allen

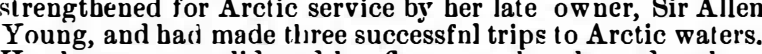
Her bows were solid, and ber flonr was sbarply wedge-shaped, to cause ber to be lifted when nipped by beavy ice. and beams were of beavy timber. To prepare ber still mor thoroughly for severe ice service, her ability to withstand a crushing force was increased just before she sailed by the beam ten by twelve inches, with a large stanchion in the while such precautions did not save the vessel from the fate
they were intended to prevent, they still kept her afloat many months after a weaker vessel would bave found the boit tom of the sea.

The scientific equipment of the Jeannette was fairly good,
and included (besides the usual apparatus for meteorologica and climatic observations, surveying, tidal observations, and so on) a movable olsservatory with a large telescope, abundant photograplic apparatus and materials, a powerful
electric ligbt, and two bundred miles of telephone wire with instruments for keeping up communication with exploring parties at a distance from the ship.

When she sailed from San Francisco July 8, 1879, the Jeannette was manned by eight officers and a crew of twentyDe Long, U.S.N., born in New York. aged 35; Executive Officer, Lient. Charles W. Chipp, U.S.N., of Kingston; N. N. Y., aged 30; Navigator, Lieut. Jobn W. Danenbauer, U.S
N., of Chicago, aged 30; Surgeon, Passed Asst. Surgeou Jame M. M. Ambler, U.S.N., of Virginia, aged 31 , Engineer, Scientist, Jerome J. Collins, a native of Ireland, 38 years of age; Naturalist and Taxidermist, Raymond L. Newcomb, New were all in the prime of life, and able to bear hardships. Two letiers were received from $\mathrm{Mr}$. Collins before the eannette left St. Lawrence Bay for the pole, the last date being August 27, 1879 . The subsequent bistory of the ves-
sel is compactly told in the official report of Chief Engineer "Melville, one of the survivors. He says, in part: th sighted Herald Island. Continued to work through the 